Article

\title{
Evaluation of a Brief Intervention to Reduce Cell Phone Use
}

\author{
Brian J. Piper ${ }^{1}$, Shay M. Daily ${ }^{2.3}$, Sarah L. Martin ${ }^{4}$ Maurice W. Martin ${ }^{2 *}$ \\ 1 Geisinger Commonwealth School of Medicine; bpiper@som.geisinger.edu \\ 2 University of Maine at Farmington; shay.daily@maine.edu \\ 3 University of Southern Maine; shay.daily@maine.edu \\ 4 Husson University; martinsar1001@gmail.com \\ 5 University of Maine at Farmington; maurice.martin@maine.edu \\ * Correspondence: maurice.martin@maine.edu
}

\begin{abstract}
Excessive cell phone use contributes to distracted driving, may increase risk for automobile accidents, and a minority of mobile phone users exhibit behaviors consistent with technological addiction. The purpose of this study was to determine whether cell phone beliefs and behaviors could be changed by a brief educational encounter. The Theory of Reasoned Action provided a lens for viewing attitudes and behavior. A one-week pre-post design with a thirty-day follow-up was used with participants $(\mathrm{N}=$ $215,67.0 \%$ female, age $=20.0 \pm 1.6$ ) assigned to a peer led intervention or comparison groups. The intervention included cell-phone educational materials. A short index of cell phone behavior was developed which showed good internal consistency with a Cronbach's alpha of .81 . The intervention group "agreed" or "strongly-agreed" more than the comparison group on five of the seven areas of cell phone beliefs and behaviors ( $\mathrm{p}<0.05$, item Cohen's $d=.32$ to .47 , total $d=.50$ ) at one-week following receipt of informational materials. We conclude that attitudes and behaviors regarding cell phones are malleable and susceptible to change in young-adults following a brief psychoeducational intervention.
\end{abstract}

Keywords: adolescent; behavior; cognition; mobile phone

\section{Introduction}

Most citizens of developed countries have access to and use cellphones, or similar mobile devices, to transfer information and data [1-3]. Cultural demands of the information age require most users to engage in use of mobile technologies to be a part of employment, education, recreation, or social-life [4-6]. Additionally, there are socially implied sanctions imposed for people who do not keep up with and use mobile technology frequently [7]. Mobile phones have replaced some other devices (e.g. cameras, address book) but may become an object of attachment [8].

There may also be adverse health consequences associated with cellphone use [9]. In adults receiving a cell phone call, glucose was elevated in the ipsilateral orbitofrontal cortex and reduced in the temporoparietal junction and anterior temporal lobe [10]. There is also an extensive body of data utilizing electroencephalographs [11]. A meta-analysis identified significant, reductions in sperm motility (-8.1\%) and viability (-9.1\%) among mobile phone users [12]. One-hour of exposure to a mobile phone to youngadults increased plasma lipid peroxidases and decreased antioxidant enzymes [13]. Understanding 
whether these acute effects increase the susceptibility to certain diseases has been the topic of intense interest [14]. Mobile phone use does not appear to increase the risk for glioblastoma [15].

There are several epidemiological findings in this area which including distracted driving which is arguably the best established and most consequential risk. There were 3,157 documented automobile fatalities involving distracted driving in the U.S. in 2016 and, of these, a cell-phone was in-use at the time of the accident for over four-hundred [16]. These numbers may be underestimates as they do not take into account how texting at night contributes to drowsy driving [17]. Two-thirds of adults (age 18-65) in the U.S. reported talking on their cell phones while driving in the past month [18]. Non-user of cell phones can be the victims of injuries sustained by user inattention [19, 20].

There is a behavioral component to wireless technology use that may increase unintentional injury and mental health issues [21]. Overuse or misuse of this technology may have parallels to addiction [2, 22, 23] although much further research may be needed to establish this [24]. People with addictive behaviors are not always able to make rational decisions regarding that behavior [2, 25, 26]. For some users, an inordinate amount of time is spent in non-productive activities that cut into time spent on healthier endeavors [17, 27].

The millennial generation, born between 1982 and 2002 [28, 29], may have a special relationship with technology [7]. This is the first generation to grow-up with mobile information-based technology being likened to adequate educational preparation and success as an adult [30]. Educational leaders have spent an enormous amount of time, money, and administrative resources continuously upgrading modern education paradigms to procure technologically friendly environments [31,32]. Millennials are more likely than prior generations to demand and use technology in innovative ways to enhance their lives [33, 34]. However, it turns out that their focus is primarily for social activities rather than academic or professional. Millennials, primarily traditional college age students, spent an average of 14 hours texting, 6.5 hours talking on the phone, and 6.5 hours using social media sites per week with some sending over 200 texts in a day [35].

The Theory of Planned Behavior has been refined by Ajzen and colleagues over the past fourdecades [36-38]. Behavior is viewed as guided by beliefs about the consequences, the normative expectations of others, and the presence or absence of factors that may impact it. These behavioral beliefs, normative beliefs, and control beliefs contribute to the attitude toward the behavior, the subjective norm, and perceived behavioral control, respectively, which together result in behavioral intention [37]. The Ajzen model has been widely utilized in such diverse areas as nutrition [39], exercise [40], and responsible drinking [41].

The purpose of this controlled study was to explore the likelihood of behavior change regarding mobile devices following a brief educational intervention to millennials. This research question was embedded within the Theory of Reasoned Action and Planned Behavior [36-38]. We found that cell phone beliefs were transiently modified following this intervention.

\section{Materials and Methods}

\section{Participants}

The participants were young-adult college students $(\mathrm{N}=215,67.0 \%$ female, age $=20.0$, Min $=17$, Max $=28$ years).

\section{Procedure}

Instrument development: Research team members held meetings to develop reliable quantitative surveys with items based in concepts from the Theory of Reasoned Action [36-38]. Drafts of each instrument were piloted using demographically similar non-participant groups.

A comprehensive search of the literature was conducted regarding the potential for negative health effects associated with cellular phone use including sleeplessness, injury and other situations and behaviors 
deleterious to human health. Using these results, a brief, one-page educational fact sheet was produced to use as an intervention tool (Supplemental Appendix 2).

As part of the pre-intervention survey, demographic and general cell phone information (cell phone type and basic usage frequency), were collected. The survey also included items based in the Theory of Reasoned Action and Planned Behavior, transitioning from values to attitude and intention such as: "I believe there may be negative health effects related to cell phone use" and "I should change some of my behaviors when it comes to my cell phone use" (Appendix 1). When instruments and tools were satisfactory to the research team, approval was obtained from a university IRB.

Design: An experimental study design was employed. It was a one-week pre- post-intervention design with a subset of participants also completing a 30-day follow-up. Due to the potential benefits of the intervention, delayed intervention was used with the comparison group assuring the ethical treatment of all participants. The data collection protocol was determined by the research team and data collection packets were provided to each data collector. Due to the public-health (e.g. distracted driving) risks associated with cell-phone use, participants were assigned to the intervention or comparison groups in an approximately 3:1 ratio.

The one-page fact sheet was provided to the intervention group immediately after the preintervention survey was completed. One week later, the first post-intervention survey (note that this measure was different than the baseline instrument) was administered to intervention and comparison groups. The methodology was convenience sampling completed spring of 2014. Students had a list of who they recruited initially and followed up with them a month later. Data collectors were trained in the classroom, with practice sessions, then with a timeline within the semester and they recruited participants who met the criteria (e.g., had a cell phone). A subset of both groups completed the post-intervention survey at one-month after the baseline. The comparison group received it immediately after the second (i.e. one-month) post-intervention survey (See Appendix A for the instrument). The fact sheet was shared with the comparison group members at this juncture after the second post-test data had been obtained. There were seventeen volunteer data collectors who were trained to gain written informed consent, administer the survey, and provide the fact sheet effectively. Each data collector was charged to recruit twenty willing potential participants who would be assigned to either an intervention or a comparison group. All potential participants were "cold contacts" of the millennial generation $($ age $<30)$ attending a public liberal arts institution in the northeastern United States. Recruitment commonly occurred in public areas. No incentives were offered for participation.

\section{Statistical Analyses}

Descriptive statistics were used to describe the characteristics of both groups. We compared cell phone use and attitudes and intentions for the two groups. Differences between groups on parametric measures were expressed in terms of Cohen's $d$ [42]. Comparisons between the intervention versus the comparison group at baseline and post-test intervals (one-week and one-month), as well as completers and post-test non-completers, were analyzed in SYSTAT, version 13.1 (Chicago, IL) with alpha set at 0f.05. Exploratory analyses examined sex differences. Internal consistency was determined with Cronbach's alpha. A total index of cell-phone attitudes and behaviors was calculated by summing the seven post-test ratings $(1=$ strongly agree to $5=$ strongly disagree), with the two negatively worded items reverse scored. Test-retest reliability was evaluated with a Pearson correlation. Figures were prepared with GraphPad Prism, version 6.07 (La Jolla, CA).

\section{Results}

Participant demographics and baseline characteristics are provided in Table 1. No demographic or cell phone related variables differed significantly between groups at baseline. Parametric analysis identified one item "I sometimes miss things going on around me (i.e. conversations, class lectures, etc.) because I am doing something on my cell phone" at baseline between the comparison $(2.5 \pm 0.7)$ and the intervention $(2.8 \pm 0.8, p \leq .005)$ but no other 
differences $(p>.18)$. The internal consistency of the 12-item mobile-phone baseline assessment (questions 1 to 12 in Supplemental Appendix 1) was 0.78 .

Table 1. Demographic and baseline characteristics of participants. APercent agree or strongly agree. Some items are truncated (see Supplemental Appendix 1 for full item wording). $\mathrm{N}$ is lower on select items due to nonresponses.

\begin{tabular}{|c|c|c|c|}
\hline & nparison $(\mathrm{N})$ & Intervention $(\mathrm{N})$ & p value \\
\hline Age (years, Mean \pm SD) & $20.0 \pm 1.9(60)$ & $20.1 \pm 1.6(155)$ & .95 \\
\hline Female $(\%)$ & $63.3(60)$ & $68.4 \%(155)$ & .59 \\
\hline Smartphone ownership & $79.3 \%(58)$ & $79.9 \%(154)$ & .93 \\
\hline I bring my cell phone everywhere I go. ${ }^{\mathrm{A}}$ & $98.3 \%(60)$ & $91.6 \%(155)$ & .14 \\
\hline If I forgot my cell phone, I feel stressed or anxious. ${ }^{A}$ & $59.3 \%(59)$ & $56.2 \%(153)$ & .80 \\
\hline If my cell phone dies, I feel anxious. ${ }^{A}$ & $57.6 \%(59)$ & $52.6 \%(154)$ & .61 \\
\hline I check it in a setting where use is discouraged. ${ }^{A}$ & $56.7 \%(60)$ & $47.7 \%(155)$ & .31 \\
\hline My phone is one of my most important possessions. ${ }^{\mathrm{A}}$ & $52.5 \%(59)$ & $50.6 \%(154)$ & .93 \\
\hline I miss things going on around me because of phone. ${ }^{\mathrm{A}}$ & $50.0 \%(60)$ & $36.2 \%(152)$ & .09 \\
\hline At times I talk on the phone while driving. A & $70.0 \%(60)$ & $76.1 \%(155)$ & .45 \\
\hline At times I text while driving. A & $43.1 \%(58)$ & $40.3 \%(153)$ & .86 \\
\hline I sleep with my cell phone within reach. ${ }^{\mathrm{A}}$ & $88.3 \%(60)$ & $84.4 \%(154)$ & .61 \\
\hline I view my cell phone as a necessary expense. ${ }^{\mathrm{A}}$ & $64.4(59)$ & $68.8(154)$ & .65 \\
\hline I usually keep my cell phone on my person. ${ }^{A}$ & $86.4 \%(59)$ & $88.9 \%(153)$ & .80 \\
\hline I feel socially isolated without my phone. ${ }^{\mathrm{A}}$ & $31.7 \%(60)$ & $31.4 \%(153)$ & .97 \\
\hline I believe there may be negative social side effects. ${ }^{A}$ & $81.7 \%(60)$ & $86.4 \%(154)$ & .51 \\
\hline
\end{tabular}


Figure 1 depicts the mean ratings at the one-week post-test. The intervention scored significantly lower $(1=$ strongly agree to $5=$ strongly disagree) on three of the five positively worded items $(d=.32, .44$, and .35$)$. The fourth item, "I plan to keep my cell phone away from my body more often", approached common statistical thresholds $(p=.054)$. The two reverse worded items, "I am not concerned at all about my cell phone use and behaviors", "I am not going to change the wa y I use my cell phone at all", showed the opposite pattern with significantly higher ratings $(d=.40$ and .47$)$. Non-parametric analyses showed the same general pattern with significant differences favoring the intervention on four items (Supplementary Figure 1).

Figure 1. Mean rating on cell phone behaviors $( \pm S E M)$ in young-adults at the post-test in the Comparison $(\mathrm{N}=60)$ and Intervention $(\mathrm{N}=155)$ groups. Item 1 : I am concerned that my cell phone use has negative effects on my health, 2: I am concerned that my cell phone use has negative effects on the environment, 3: I should change some of my behaviors when it comes to my cell phone use, 4: I plan to keep my cell phone away from my body more often, 5 : I plan to use a hands free device for calls when I can, 6: I am not concerned at all about my cell phone use and behaviors, 7: I am not going to change the way I use my cell phone at all. Rreverse worded item, ${ }^{\mathrm{A}} p<.05 ; \mathrm{B} p<.005$ versus Comparison.

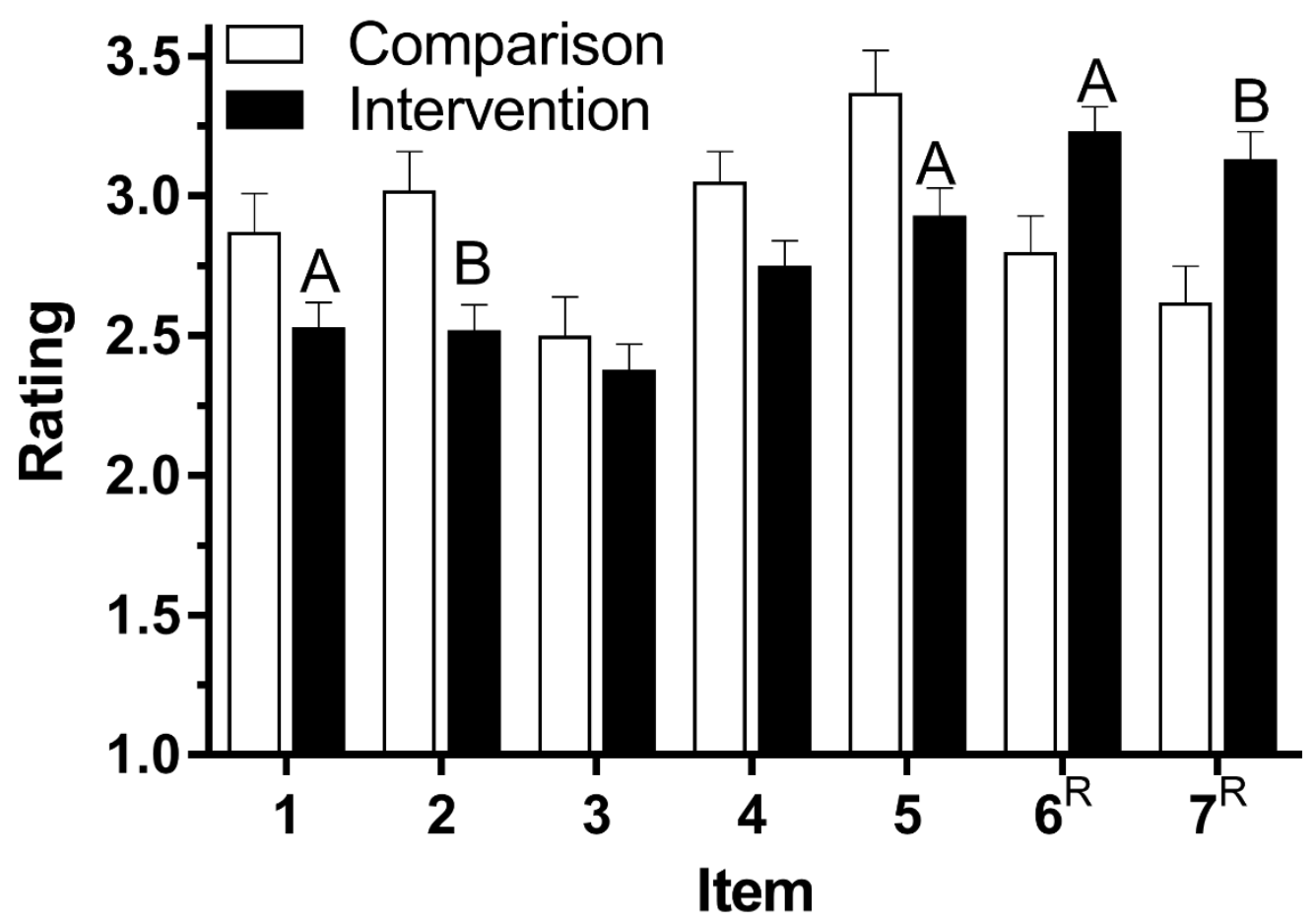

The internal consistency of the 7 -item post-intervention measure was 0.82 . Therefore, a total index of mobile phone behaviors was created. The Intervention scored lower than the Comparison (Figure 2, $p$ $<.005, d=.50)$. The effect size was larger in females $(d=.57)$ than males $(d=.38)$ but similar in smartphone $(d=.54)$ and non-smart-phone $(d=.47)$ users. At one-month after the baseline, a subset of participants (33.3\% of the original comparison and $39.4 \%$ of the intervention) were reassessed for the second Post-Test. The completers were 1.5 years younger than non-completers (Completers $=19.2 \pm 1.5$, Non-completers $=$ $20.6 \pm 1.3, p<.0005)$. More completers $(79.5 \%)$ than non-completers $\left(59.2 \%, \chi^{2}(1)=8.85, p<.005\right)$ viewed their cell phone as a necessary expense but groups were otherwise indistinguishable (i.e. not statistically different, Supplemental Table 1). The intervention and comparison were equivalent on individual items $(p>.09)$ or the total score $(p=.32)$ at one-month. The Intervention at one-month was still lower than the 
Comparison at one-week $(p \leq .01$, Figure 2). Further, the Comparison at one-month $(17.8 \pm 0.7)$ was significantly decreased relative to the Comparison at one-week $(21.4 \pm 0.6, p \leq .001)$. The majority of the intervention condition agreed that they learned something new from the fact-sheet at the first $(87.1 \%)$ and second $(65.6 \%)$ Post-Tests.

Figure 2. Mean rating on cell phone behaviors ( $($ SEM) in young-adults at the post-intervention $(\mathrm{N}=212)$ and 30 -days follow-up $(\mathrm{N}=84)$ post-test. ${ }^{A} p \leq .01$ versus Comparison at post-test.

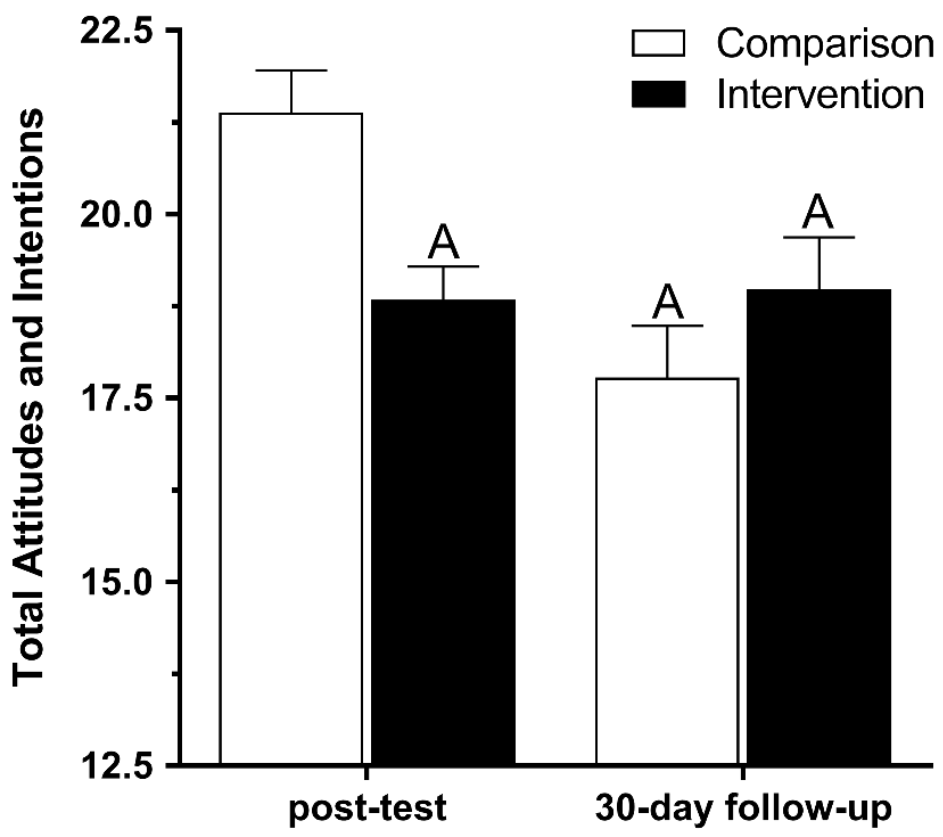




\section{Discussion}

This report makes two contributions to the public health and behavioral addiction fields. First, this controlled study suggests that mobile phone use attitudes and behaviors are fluid, and perhaps, malleable in young-adults. Second, this investigation provide some preliminary psychometric support for the development of a relatively abbreviated instrument to quantify cell phone behaviors. The prevalence and use of information technology by millennials in the form of mobile devices is well established [3,9, 17]. The present findings that cell phone attitudes and behaviors can be modified, at least transiently, may be of particular interest to mental health providers with patients, or their family members, interested in reducing their mobile phone use [23]. Further, the development of cell phone interventions may be useful for individuals caught repeatedly violating laws prohibiting texting and driving. The theory of planned behavior has previously been employed to better understand cell phone use [43-46]. However, these have been cross-sectional [43-45] or have not yet reported the randomized findings [46]. The feasibility of curtailing that multi-faceted usage has not yet been well established. This investigation identified a small-moderate effect size with a brief-intervention at a short (one-week) interval.

Although not the primary objective, this study also adds to other findings to develop other abbreviated measures of problematic cell phone use [47-51]. A Smartphone Addiction Inventory has been developed for cell phone users that can read Mandarin which showed excellent internal consistency and very good two-week test-retest reliability in a primarily male young-adult sample [51]. The internal consistency of both the baseline and Post-Test instruments used in this effort were sufficient. However, this was not the case for the test-retest reliability. However, as only a minority of participants were available for the one-month Post-Test, any inferences regarding the data at this interval (correlations or means) should be made with great caution.

Some additional limitations and future directions are also noteworthy. First, although the participants in this controlled study provided evidence that they changed their cell phone use behaviors, and this post-intervention pattern appeared to be persistent (relative to the comparison group at one-week), the endpoints measured were based on self-report. Future efforts to reduce phone use could also incorporate more objective measures like phone bills or an application that records mobile phone use [52] or use measures that have been previously validated. We employed newly developed measures and provided some psychometric data. Further information about test-retest reliability, and validation of self-reported use patterns relative to phone records is needed. Second, the participants were young-adults and disproportionately female. As high-school and college-age students have the highest mobile phone usage [17], and some data indicates that females have more problematic cell phone use patterns [53], we view the sample characteristics as a strength of this report. However, additional longitudinal studies will be necessary to further characterize the persistence of mobile phone attitudinal and behavior changes following interventions. Third, this investigation was completed with a normative sample of young-adults. More intense, and repeated, interventions may be needed for individuals with more excessive, and problematic, mobile-phone attitudes and behaviors [23].

\section{Conclusions}

In conclusion, this investigation provides evidence that cell phone use can be modified, at least temporarily, in young-adults.

Supplementary Materials: The following are available online at www.mdpi.com/xxx/s1, Figure S1: Percent agreement on cell phone behaviors at the one-week post-test, Table S1: Demographic and baseline 
characteristics of participants that did (completers), and did not (non-completers), participate in the onemonth Post-Test, Appendix S1: Pre and post intervention survey completed by participants. Appendix S2: Cell phone fact sheet.

Author Contributions: “Conceptualization, S.M.D and M.W.M.; methodology, M.W.M \& S.M.D; software, B.J.P.; formal analysis, B.J.P.; investigation, S.M.D.; resources, M.W.M.; data curation, S.M.D.; writingoriginal draft preparation, S.M.D., S.L.M., M.W.M.; writing-review and editing, B.J.P., S.M.D., S.L.M., M.W.M.; visualization, B.J.P.; supervision, M.W.M.; project administration, M.W.M.; All authors have read and agreed to the published version of the manuscript.

Funding: This research received no external funding. Software was provided by Husson University School of Pharmacy and the NIEHS (T32 ES007060-31A1).

Acknowledgments: The efforts of the peer educators are gratefully acknowledged.

Conflicts of Interest: The authors declare no conflict of interest. The funders had no role in the design of the study; in the collection, analyses, or interpretation of data; in the writing of the manuscript, or in the decision to publish the results.

\section{References}

1. International Telecommunications Union. The world in 2014. ICT facts and figures. Geneva: Int. Telecommun. Union; Accessed 5/12/17 at: http://www.itu.int/en/ITUD/Statistics/Documents/facts/ICTFactsFigures2014-e.pdf

2. Salehan M, Negahban A. Social networking on smartphones: When mobile phones become addictive. Comp Hum Behav. 2013; 29(6):2632-9.

3. Zickuhrs K. Generations and their gadgets. Pew Research Center's Internet \& American Life Project. 2011. Accessed 5/1/2017 from: http://pewinternet.org/Reports/2011/Generationsandgadgets.aspx

4. Dresselhaus A, Shrode F. Mobile technologies and academics: Do students use mobile technologies in their academic lives and are librarians ready to meet this challenge? Information Technol Librar. 2012; 31(2):82-101.

5. Park Y, Jex SM. Work-home boundary management using communication and information technology. Int J Stress Manag. 2011; 18(2):133-152.

6. Avidan A, Yacoubi G, Weissman C, Levin PD. Cell phone calls in the operating theater and staff distractions: An observational study. J Patient Saf. 2019; 15(4):e52-e55.

7. Forgays DK, Hyman I, Schreiber J. Texting everywhere for everything: Gender and age differences in cell phone etiquette and use. Comput Hum Behav. 2014; 31:314-321.

8. Walsh SP, White KM, Young RM. Over-connected? A qualitative exploration of the relationship between Australian youth and their mobile phones. J Adolesc. 2008; 31(1):77-92.

9. Toda M, Monden K, Kubo K, Morimoto K. Mobile phone dependence and health-related lifestyle of university students. Social Behav Pers. 2006; 34:1277-84.

10. Volkow ND, Tomasi D, Wang GJ, Vaska P, Fowler JS, Telang F, et al. Effects of cell phone radiofrequency signal on brain glucose metabolism. JAMA. 2011; 305(8):808-13.

11. Roggeveen S, van Os J, Viechtbauer W, Lousberg R. EEG changes due to experimentally induced 3G mobile phone radiation. PLoS One. 2015; 10(6):e0129496.

12. Adam JA, Galloway TS, Mondal D, Esteves SC, Mathews F. Effect of mobile telephones on sperm quality: A systematic review and meta-analysis. Environ Int. 2014; 70: 106-12.

13. Moustafa YS, Moustafa RM, Belacy A, Abou-El-Ela SH, Ali FM. Effects of acute exposure to the radiofrequency fields of cellular phones on plasma lipid peroxidase and antioixidase activities in human erythrocytes. J Pharm Biomed Anal. 2001; 26(4):605-8.

14. Pawl R. Cell phones more dangerous than cigarettes! Surg Neurol. 2008; 70(5):445-6.

15. Omuro A, DeAngelis LM. Glioblastoma and other malignant gliomas: A clinical review. JAMA. 2013; 310(17):1842-50. 
16. National Highway Traffic Safety Administration. Traffic safety facts research note: distracted driving 2016. $2013 . \quad$ Ascessed 10/27/2019 at: https://crashstats.nhtsa.dot.gov/Api/Public/Publication/812517.

17. National Sleep Foundation. 2011 Sleep in America Poll: Communication Technologies and Sleep, Washington (DC): The Foundation; 2011. Accessed 10/27/2019 at: https://sleepfoundation.org/sites/default/files/sleepinamericapoll/SIAP 2011 Summary of Findings.p df.

18. Centers for Disease Control and Prevention. Mobile device use while driving--United States and seven European countries, 2011. MMWR Morb Mortal Wkly Rep. 2013; 62(10):177-82.

19. Stimpson JP, Wilson FA, Muelleman RL. Fatalities of pedestrians, bicycle riders, and motorists due to distracted driving motor vehicle crashes in the U.S., 2005-2010. Public Health Rep. 2013; 128:436-442.

20. Ayers JW, Leas EC, Dredze M, Allem JP, Grabowski JG, Hill L. Pokémon GO-A new distraction for drivers and pedestrians. JAMA Intern Med. 2016; 176:1865-6.

21. Thomée S, Dellve L, Härenstam A, Hagberg M. Perceived connections between information and communication technology use and mental symptoms among young adults - a qualitative study. BMC Public Health. 2010; 10:1066-79.

22. De-Sola Gutiérrez J, Rodríguez de Fonseca F, Rubio G. Cell-phone addiction: A review. Front Psychiatry. 2016; 7:175. PMID: 27822187.

23. Travasso C. India opens clinic to help people "addicted" to mobile phones and video games. BMJ. 2014; 349:g4439.

24. Billieux J, Maurage P, Lopez-Fernandez O, Kuss DJ, Griffiths MD. Can disordered mobile phone use be a behavioral addiction? An update and a comprehensive model for future research. Current Addiction Reports. 2015; 2:156-62.

25. Tomer JF. Addictions are not rational: a socio-economic model of addictive behavior. J Socio-Economics. 2001; 30(3):243.

26. Truong LT, De Gruyter C, Nguyen HTT. Calling, texting, and searching for information while riding a motorcycle: A study of university students in Vietnam. Traffic Inj Prev. 2017; 18(6):593-8.

27. Lepp A, Barkley JE, Sanders GJ, Rebold M, Gates P. The relationship between cell phone use, physical and sedentary activity, and cardiorespiratory fitness in a sample of U.S. college students. Int J Behav Nutr Phys Act. 2013; 10(1):79-87.

28. Rickes PC. Make way for millennials! How today's students are shaping higher education space. Planning for Higher Education. 2009; 37(2):7-17.

29. Turner P, Thompson E. College retention initiatives meeting the needs of millennial freshman students. College Student Journal. 2014; 48(1):94-104.

30. Hoskins, B. J. (2010). The art of E-Teaching. Journal of Continuing Higher Education. 2010; 58(1):53-6.

31. Ally M, Samaka M. Open education resources and mobile technology to narrow the learning divide. Int Rev Res Open Distance Learning. 2013; 14(2):14-27.

32. Coleman JK, Little SD, Lester A. Connecting services to students: New technology and implications for student affairs. College Student Affairs J 2006; 25(2):220-7.

33. Emanuel RC. The American college student cell phone survey. College Student Journal. 2013; 47(1):75-81.

34. Oblinger D. Boomers gen-xers millennials. EDUCAUSE Review 2003; 500(4): 37-47.

35. Hanson TL, Drumheller K, Mallard J, McKee C, Schlegel P. Cell phones, text messaging, and Facebook: Competing time demands of today's college students. College Teaching. 2011; 59(1):23-30.

36. Ajzen I. From intentions to actions: A theory of planned behavior (pp. 11-39). Springer Berlin Heidelberg, 1985.

37. Ajzen I. Constructing a theory of planned behavior questionnaire. 2006; Accessed 10/27/2019 at: http://people.umass.edu/ aizen/pdf/tpb.measurement.pdf.

38. Ajzen I, Fishbein M. The prediction of behavior from attitudinal and normative variable. J Exp Soc Psychol. 1970; 6(4):466-87.

39. Riebl SK, Estabrooks PA, Dunsmore JC, Savla J, Frisard MI, Dietrich AM, et al. A systematic literature review and meta-analysis: The Theory of Planned Behavior's application to understand and predict nutrition-related behaviors in youth. Eat Behav. 2015; 18:160-78. 
40. Rhodes RE, Blanchard CM, Benoit C, Levy-Milne R, Naylor PJ, Downs DS, et al. Belief-level markers of physical activity among young adult couples: Comparisons across couples without children and new parents. Psychol Health. 2014; 29:1320-40.

41. de Graaf A, van den Putte B, de Bruijn GJ. Effects of issue involvement and framing of a responsible drinking message on attitudes, intentions, and behavior. J Health Commun. 2015; 20(8):989-94.

42. Rosnow RL,Rosenthal R. Computing contrasts, effect sizes, and counternulls on other people's published data: General procedures for research consumers. Psychological Meth 1996; 1(4):331-40.

43. Bazargan-Hejazi S, Teruya S, Pan D, Lin J, Gordon D, Krochalk PC, Bazzargan M. The Theory of Planned Behavior (TPB) and texting while driving behavior in college students. Traffic Inj Prev 2017; 18(2):56-62.

44. Koh H, Mackert M. A study exploring factors of decision to text while walking among college students based on theory of planned behavior (TPB). J Am Coll Health 2016; 64(8): 619-627.

45. Khanjani N, Tavakkoli L, Bazargan-Hejazi. Factors related to cell phone use while driving based on the Theory of Planned Behavior amoun university students in Kerman, Iran. J Inj Violence Res 2019; 11:203212.

46. McDonald CC, Brawner BM, Fargo J, Swope J, Sommers MS. Development of a theoretically grounded, web-based intervention to reduce adolescent driver inattention. J Sch Nurs 2018; 34:270-280.

47. Bianchi A, Phillips JG. Psychological predictors of problem mobile phone use. CyberPsychol Behav. 2005; 8(1):39-51.

48. Foerester M, Roser K, Schoeni A, Roosli M. Problematic mobile phone use in adolescents: Derivation of a short scale MPPUS. Int J Public Health. 2015; 60:277-86.

49. Martinotti G, Villella C, Di Thiene D, Di Nicola M, Bria P, Conte G, et al. Problematic mobile phone use in adolescence: a cross-sectional study. J Public Health. 2011; 19(6):545-51.

50. Smetaniuk P. A preliminary investigation into the prevalence and prediction of problematic cell phone use. J Behav Addict. 2014; 3(1):41-53.

51. Lin YH, Chang LR, Lee YH, Tseng HS, Kuo TB, Chen SH. Development and validation of the Smartphone Addiction Inventory (SPAI). PLOS One. 2014; 9(6):e98312.

52. Lin YH, Lin YC, Lee YC, Lin PH, Lin PH, Chang LR, Tseng HW, et al. Time distortion associated with smartphone addiction: Identifying smartphone addiction via a mobile application (App). J Psychiatric Res. 2015;65:139-45.

53. Nathan N, Zeitzer J. A survey study of the association between mobile phone use and daytime sleepiness in California high school students. BMC Public Health 2013; 13:840. 
Supplemental Table 1. Demographic and baseline characteristics of participants that did (completers), and did not (non-completers), participate in the one-month Post-Test. Some items are truncated (see Appendix for full item wording). APercent "agree" or "strongly agree". $\mathrm{N}$ is lower on select items due to nonresponses.

\begin{tabular}{|c|c|c|}
\hline & & Completers $(\mathrm{N})$ \\
\hline$\underline{\text { Non-completers (N) }}$ & & \\
\hline $\begin{array}{l}\text { Age (years) Mean } \pm \text { SD } \\
\quad<.0005\end{array}$ & $19.2 \pm 1.5(88)$ & $20.6 \pm 1.3(127)$ \\
\hline $\begin{array}{l}\text { Female } \\
\qquad .47\end{array}$ & $63.6 \%(88)$ & $69.3 \%(127)$ \\
\hline $\begin{array}{l}\text { Smartphone ownership (\%) } \\
.64\end{array}$ & $81.8 \%(88)$ & $78.2(124)$ \\
\hline $\begin{array}{l}\text { I bring my cell phone everywhere I go. }{ }^{\mathrm{A}} \\
.90\end{array}$ & $94.3 \%(88)$ & $92.9 \%(127)$ \\
\hline $\begin{array}{l}\text { If I forgot my cell phone, I feel stressed or anxious. }{ }^{A} \\
.81\end{array}$ & $58.6 \%(87)$ & $56.0 \%(125)$ \\
\hline $\begin{array}{l}\text { If my cell phone dies, I feel stressed or anxious. }{ }^{\mathrm{A}} \\
.58\end{array}$ & $56.8 \%(88)$ & $52.0 \%(125)$ \\
\hline $\begin{array}{l}\text { I check it in a setting where cell phone use is discouraged. }{ }^{\mathrm{A}} \\
.94\end{array}$ & $51.1 \%(88)$ & $49.6 \%(127)$ \\
\hline $\begin{array}{l}\text { My cell phone is one of my most important possessions. }{ }^{\mathrm{A}} \\
.90\end{array}$ & $52.3 \%(88)$ & $50.4 \%(125)$ \\
\hline $\begin{array}{l}\text { I sometimes miss things because of my phone. }{ }^{A} \\
.33\end{array}$ & $44.7 \%(85)$ & $37.0 \%(127)$ \\
\hline $\begin{array}{l}\text { I talk on the phone while driving. }{ }^{\mathrm{A}} \\
.52\end{array}$ & $77.3 \%(88)$ & $72.4 \%(127)$ \\
\hline $\begin{array}{l}\text { I text on the phone while driving. }{ }^{\text {A }} \\
.58\end{array}$ & $38.4 \%(86)$ & $43.2 \%(125)$ \\
\hline $\begin{array}{l}\text { I sleep with my cell phone within reach. }{ }^{\mathrm{A}} \\
\quad .45\end{array}$ & $82.8 \%(87)$ & $87.4 \%(127)$ \\
\hline $\begin{array}{l}\text { I view my cell phone as a necessary expense. }{ }^{\mathrm{A}} \\
.003\end{array}$ & $79.5 \%(88)$ & $59.2 \%(125)$ \\
\hline $\begin{array}{l}\text { I usually keep my cell phone on my person. }{ }^{\mathrm{A}} \\
.16\end{array}$ & $83.9 \%(87)$ & $91.2 \%(125)$ \\
\hline $\begin{array}{l}\text { I feel socially isolated when I don't have my phone. }{ }^{A} \\
1.00\end{array}$ & $31.4 \%(86)$ & $31.5 \%(127)$ \\
\hline $\begin{array}{l}\text { There may be negative social side effects to cell phones. }{ }^{\mathrm{A}} \\
\quad .84\end{array}$ & $86.2 \%(87)$ & $84.3 \%(127)$ \\
\hline
\end{tabular}


Supplemental Appendix 1. Pre (top) and post intervention survey (bottom) completed by participants.

Name:

Code: DC - XX OB - XX

Please write a number in the space provided next to each statement indicating how much you agree or disagree with the following statements:

Note: All coding records are confidential and will be destroyed after the instruments are turned in to the researcher. You may choose to not answer any question you feel uncomfortable with.

$1=$ Strongly agree $2=$ Agree $3=$ Disagree $4=$ Strongly disagree

1. I bring my cell phone everywhere I go.

2. If I forget my cell phone, I feel stressed and/or anxious.

3. If my cell phone dies and I do not have a charger, I feel stressed and/or anxious.

4. In a setting where cell phone use is discouraged (i.e. in class or at work) I check it anyway.

5. My cell phone is one of the most important possessions I own.

6. I sometimes miss things going on around me (i.e. conversations, class lectures, etc.) because I am doing something on my cell phone.

7. At times I text while driving. (Note: In Maine, texting while driving is illegal.)

8. At times I talk on the phone while driving.

9. I sleep with my cell phone within reach.

10. I view my cell phone bill as a necessary expense.

11. I usually keep my cell phone on my person.

12. I feel socially isolated when I don't have my cell phone with me.

13. I believe there may be negative social side effects to using cell phones. (circle one)

$$
\text { Yes No Really not sure }
$$

14. I believe there may be negative health effects related to cell phone use. (circle one)

$$
\text { Yes No Really not sure }
$$

15. I believe there may be negative environmental effects related to cell phone use. (circle one)_

$$
\text { Yes No Really not sure }
$$

$1=$ Strongly agree $\quad 2=$ somewhat agree $\quad 3=$ neither agree nor disagree $\quad 4=$ somewhat disagree $\quad 5=$ Strongly disagree

1. I learned something new from the Intervention Fact Sheet.

2. I am concerned that my cell phone use has negative effects on my health.

3. I am concerned that my cell phone use has negative effects on the environment.

4. I should change some of my behaviors when it comes to my cell phone use.

5. I plan to keep my cell phone away from my body more often.

6. I plan to use a hands free device for calls when I can.

7. I am not concerned at all about my cell phone use and behaviors.

8. I am not going to change the way I use my cell phone at all. 
Supplemental Figure 1. Percent agreement on cell phone behaviors at the one-week post-test in the Comparison $(\mathrm{N}=60)$ and Intervention $(\mathrm{N}=155)$ groups. Item 1 : I am concerned that my cell phone use has negative effects on my health. Item 2: I am concerned that my cell phone use has negative effects on the environment. Item 3: I should change some of my behaviors when it comes to my cell phone use. Item 4: I plan to keep my cell phone away from my body more often. Item 5: I plan to use a hands free device for calls when I can. Item 6: I am not concerned at all about my cell phone use and behaviors. Item 7: I am not going to change the way I use my cell phone at all. Items were rated $1=$ strongly agree, $2=$ agree, $3=$ neutral, $4=$ disagree, and $5=$ strongly disagree except items 6 and 7 which were ${ }^{R}$ reverse coded. ${ }^{A} p<.10 ;{ }^{B} p<.05 ;{ }^{C} p<.005$.

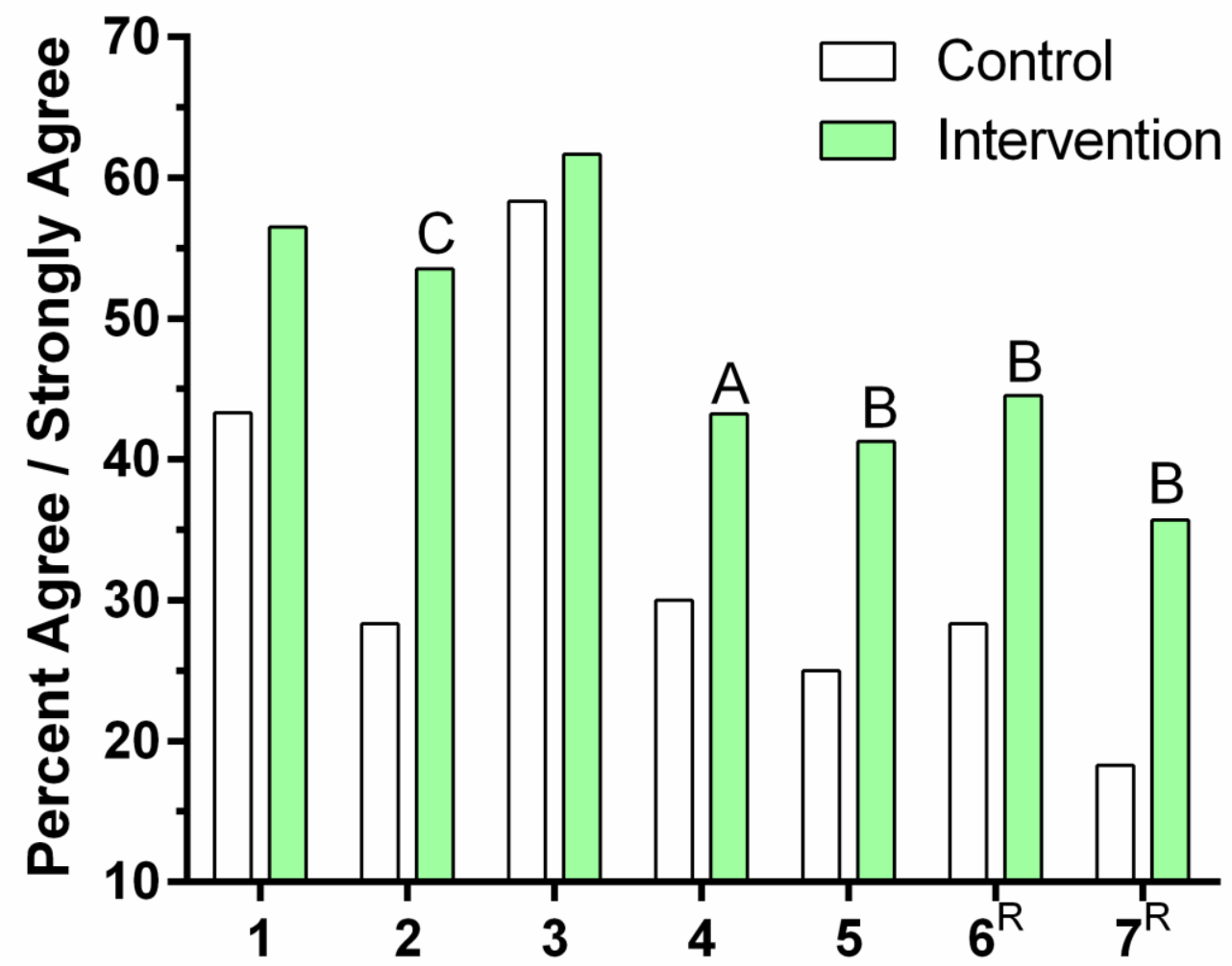


3 Please read the following summaries of findings from scientific studies before continuing on to the 4 next page.

5 1. People who use cell phones for ten years are $30 \%$ more likely to develop brain tumors than people 6 who rarely use them. ${ }^{1}$

7 2. Electromagnetic radiation has been shown to decrease sperm motility. ${ }^{2}$

8 3. The International Agency for Research on Cancer classifies EMR from cell phones as possibly 9 carcinogenic to humans. ${ }^{3}$

10 4. Electromagnetic radiation (EMR, emitted from cell phones) is strongly related to reproductive 11 health problems, especially in men. ${ }^{4}$

12 5. Using a hands free device, as well as limiting the length and number of calls you partake in can 13 greatly reduced harmful EMR exposure ${ }^{5}$

14 6. In 2011, 3,331 people were killed in crashes involving a distracted driver. ${ }^{6}$

15 7. Cell Phone dependency can be closely associated with materialism (e.g. shopping addiction) and 16 is especially prevalent amongst teens and young adults. ${ }^{7}$

1 Deltour, I., Johansen, C., Auvinen, A., Feychting, M., Klaeboe, L., Schuz, J. (2009). Time trends in brain tumor incidence rates in Denmark, Finland, Norway, and Sweden, 1974 - 2003. Journal of National Cancer Institute, Brief Communications 101, $1721-1724$.

2 Rago, R., Salacone, P., Caponecchia, L., Sebasianelli, L., Macucci, I., Calogero, AE., et al. (2013). The semen quality of the mobile phone users. Journal of Endocrinal Investigation, Retrieved from: http://www.ncbi.nlm.nih.gov/pubmed/23722985

3 World Health Organization. (2011). Electromagnetic Fields and Public Health: Mobile Phones. Retrieved from: http://www.who.int/mediacentre/factsheets/fs193/en/

4 Rago, R., Salacone, P., Caponecchia, L., Sebasianelli, L., Macucci, I., Calogero, AE., et al. (2013). The semen quality of the mobile phone users. Journal of Endocrinal Investigation, Retrieved from: http://www.ncbi.nlm.nih.gov/pubmed/23722985

5 World Health Organization. (2011). Electromagnetic fields and public health: Mobile Phones. Retrieved from: http://www.who.int/mediacentre/factsheets/fs193/en/

6 Centers for Disease Control and Prevention (CDC). (2013). Mobile device use while driving more common in the US than in several European countries. Retieved from: http://www.cdc.gov/media/releases/2013/p0314_driving_mobile_device_use.html

7 Roberts, J., Pirog III, S. (2012). A preliminary investigation of materialism and impulsiveness as predictors of technological addictions among young adults. Journal of Behavioral Addictions, 2(1), 56 - 62 . 